\title{
Solon and the Rhetoric of Stasis
}

\section{William Allan (University College, Oxford)}

We cannot separate 'Solon the poet' from 'Solon the politician', and the role of the poet as a public figure in archaic Greece is nowhere clearer than with him. As archon in 594/3 BC, Solon introduced reforms that affected almost every area of the Athenian state, and later tradition celebrated him as a wandering wise man, one of the Seven Sages. Solon's reputation for wisdom and moderation ${ }^{1}$ led Herodotus, for example, to depict his encounter in Sardis with Croesus, king of Lydia, who fatally ignores Solon's reflections on the dangers of excessive wealth and the uncertainty of human life. ${ }^{2}$

The egalitarian thrust of Solon's legal, economic, and political reforms make him a key figure in the development of democracy at Athens. ${ }^{3}$ By weakening the power of the wealthy elite and their inherited privileges, and by focusing on the cohesion and benefit of the community as a whole, Solon laid the foundations for the classical concept of the free Athenian citizen, who is expected to play a part in running the city. ${ }^{4}$ By the late fifth century Solon had become a quasi-legendary figure honoured in hero-cult, ${ }^{5}$ hailed by some as the founding hero of Athenian democracy, by others as the guardian of a more conservative ancestral constitution (or patrios politeia). Although such attempts to co-opt Solon's authority have influenced his presentation in the ancient sources, I would agree with P. J. Rhodes that there is likely to be more history than myth in the surviving accounts of his laws and reforms. ${ }^{6}$

In the surviving fragments we see Solon using all his skills as a poet to persuade his audience of the need for change and the wisdom of his policies. ${ }^{7}$ Most of Solon's poems were composed for performance at symposia, but we cannot rule out performance in more public settings - for example, at public meetings or city festivals (see on frr. 1-3, 36). In any case, it is striking how, unlike Alcaeus or Theognis, for example, who address an audience that shares their social and political views, Solon balances the competing demands of different sections of Athenian society, and uses

\footnotetext{
${ }^{1}$ The latter a recurring idea in his political poems: see esp. frr. 4c, 5, 6, 7, 36, 37. The fragments of Solon and other iambic and elegiac poets follow the text and numeration of West 1992.

${ }^{2}$ It is possible that Croesus encountered Solon at the start of his reign (560 BC), but not (as Herodotus has it) within ten years of Solon's archonship (c. 594/3-584/3 BC).

${ }^{3}$ Solon's main economic reforms came in response to growing tensions between rich Athenian overlords and poor farmers. Solon's solution, commonly known as the 'shaking-off of burdens' (or seisachtheia: see fr. 36), probably meant that the farmers were no longer obliged to render up a sixth of their produce to their overlords; it also liberated those Athenians who had been enslaved for debt, repatriated those who had been sold abroad, and made the future practice of enslavement for debt illegal (cf. Stanley 1999: 210-18, Harris 2002, Forsdyke 2006: 347). Solon's political reforms were geared to extending decision-making power beyond a narrow aristocratic elite. He created a new council (ßou $\lambda$ ń) of 400 members to consider business for the assembly. He also divided the citizenry into four classes based on the size of their annual harvest; although only the three highest classes could hold political office, the poorest were allowed to attend the assembly and thus have a say in the running of the state.

${ }^{4}$ Cf. Manville 1990: 124-56, Lewis 2006: 6.

${ }^{5}$ Kearns 1989: 198.

${ }^{6}$ Rhodes 2006: 259.

${ }^{7}$ As regards the chronology of the poems, some political pieces are likely to predate Solon's archonship (e.g. frr. 4, 4a, 4c), while others are evidently later because they defend his reforms (frr. 5, $34,36,37$ ) or boast of having resisted the chance to become a tyrant (frr. 32-3).
} 
all his rhetorical skill to persuade his listeners to accept his political and ethical values. $^{8}$

Solon's success in achieving such a balance is mirrored in his later fame as a $\delta ı \alpha \lambda \lambda \alpha$ KTńs - that is, as a 'reconciler' or 'mediator' between the warring factions of Athens. The Aristotelian Constitution of Athens explains his rise to power as follows ([Ath. Pol.] 5.1-2, trans. Rhodes):

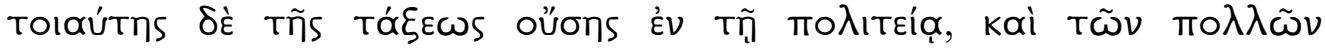

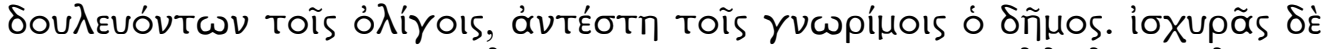

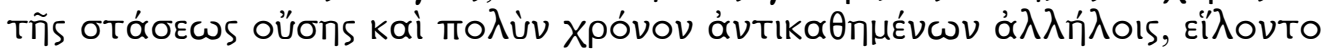

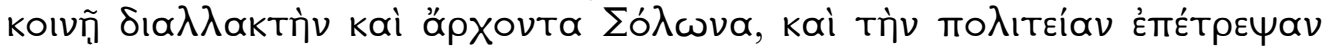

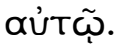

While the state was organized in this way, and the many were enslaved to the few, the people rose against the notables. The strife was fierce, and they held out against one another for a long time. Eventually the two sides agreed to

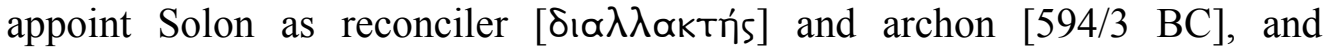
entrusted the state to him.

My aim here is to consider how Solon recasts traditional imagery of warfare and violence both to persuade his audience of the evils of stasis and to bolster his persona as a 'reconciler' and peacemaker.

Perhaps the first thing to stress is that Solon is pleading for internal peace and the avoidance of civil war - he is not opposed to warfare per se, as the fragments of his poem Salamis make clear (Sol. frr. 1-3):

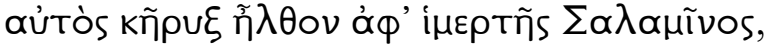

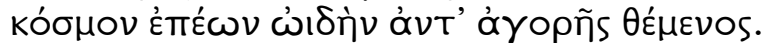

I have come as a herald from lovely Salamis, adopting song, an ordered form of words, instead of speech.

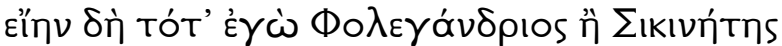

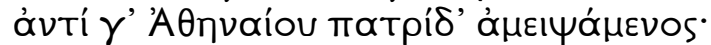

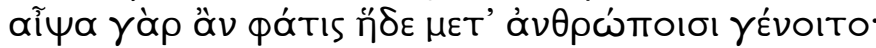

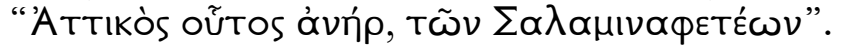

In that case I'd rather be from Pholegandrus or Sicinus rather than Athens, exchanging my homeland, for soon this report would spread among men: 'This man's an Athenian, one of those Salamis-ceders.'

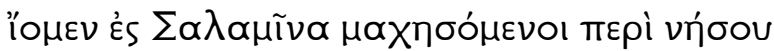

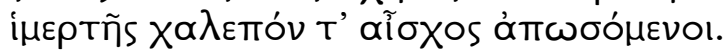

Let us go to Salamis to fight for the lovely isle and clear away harsh disgrace.

\footnotetext{
${ }^{8}$ With a historically significant figure like Solon it is particularly tempting to interpret the primary narrator in a simple biographical manner, but while Solon's poetry clearly draws on his own experiences as a politician and legislator, he too must fashion a convincing authorial persona. Solon's self-presentation underlines his role as a moderate and impartial reformer, not a revolutionary, and by drawing on the language, ethics, and theology of Homer and Hesiod (especially in frr. 4 and 13), Solon imbues his commitment to justice and communal values with the authority of traditional wisdom.
} 
Solon's poem (originally 100 lines long, according to Plutarch, Sol. 8.2) engages forcefully with Athens' war against Megara for control of Salamis. As in the martial elegies of Callinus and Tyrtaeus, the speaker of Salamis stages a dramatic call to arms. Only three fragments (eight lines in total) survive, but they are enough to show Solon's skilled use of persona and emotion, building on the elegiac tradition of martial exhortation.

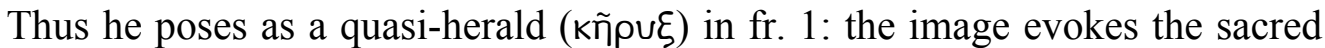
inviolability and trust invested in the role of herald, ${ }^{9}$ encouraging the audience to see Solon as a credible messenger acting in the best interests of Athens. Line 2 ('adopting song, an ordered form of words, instead of speech') plays on the incongruity of a singing herald and emphasizes that Solon's message will be all the more memorable for being in verse. Since kóouos denotes civic order and good government, ${ }^{10}$ the

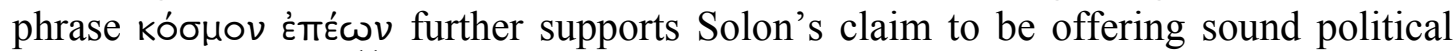
and military advice. ${ }^{11}$ In fr. 2 Solon's quotation of anonymous criticism mirrors the use of TIS-speeches in Homer ${ }^{12}$ and evokes the shame of losing Salamis. His sarcastic neologism $\Sigma \alpha \lambda \alpha \mu ı \alpha \phi \varepsilon ́ t \eta n s$ ('one of those Salamis-ceders') gives the imaginary insult a punchy, humiliating ending. Moreover, the neologism itself hints at the widespread notoriety of losing Salamis ('Salamis-ceder' will become a familiar term), making the Athenians' shame all the more intense. Finally, in fr. 3, as is typical of the martial exhortation of Callinus and Tyrtaeus (cf. Call. fr. 1, Tyrt. frr. 10, 11) the strong language of disgrace ( $\chi \propto \lambda \varepsilon \pi$ óv T' đĩoXos $)^{13}$ motivates the call to arms.

So external war is noble and to be pursued where necessary, the problem is the civil war threatening Athens, which forms the background to all of Solon's surviving political poetry. Let us begin with fr. 4:

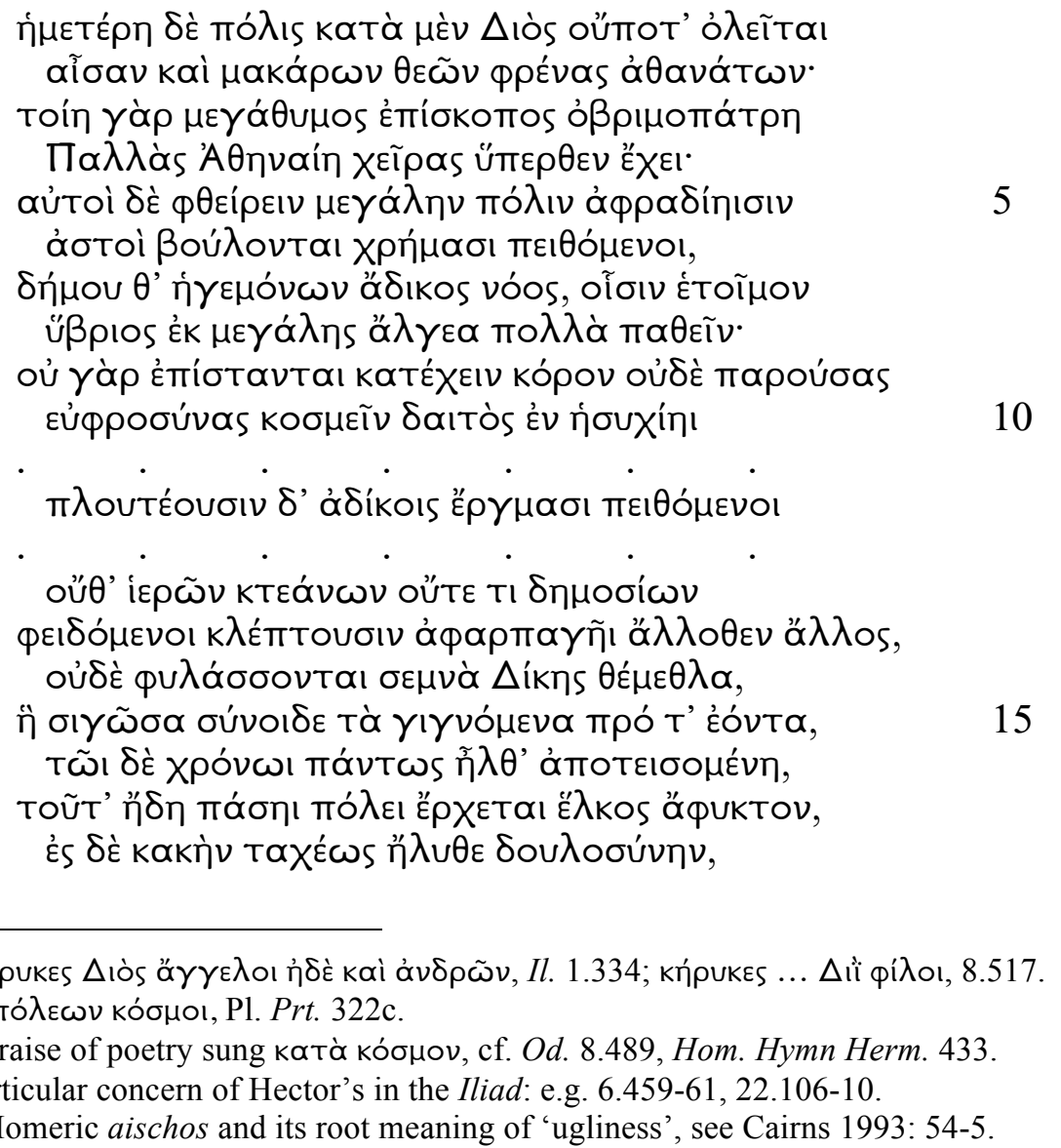

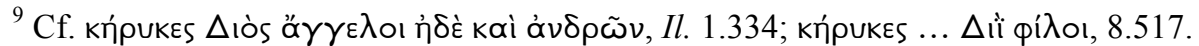

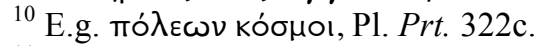

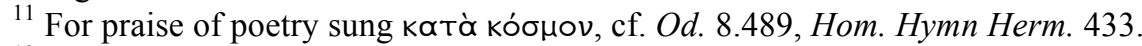

${ }^{12}$ A particular concern of Hector's in the Iliad: e.g. 6.459-61, 22.106-10.

${ }^{13}$ For Homeric aischos and its root meaning of 'ugliness', see Cairns 1993: 54-5.
} 


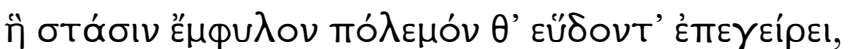

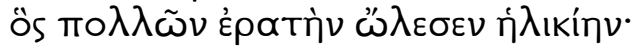

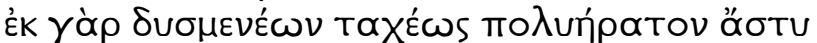

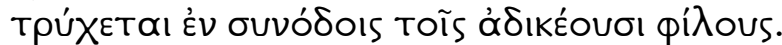

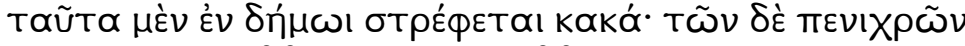

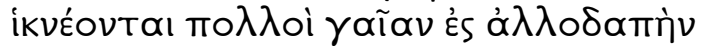

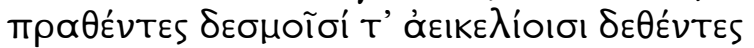

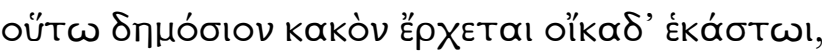

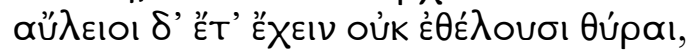

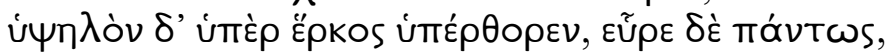

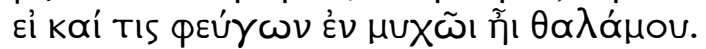

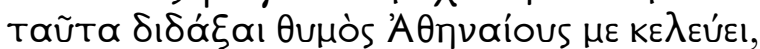

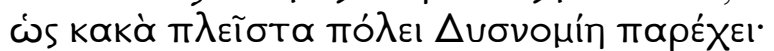

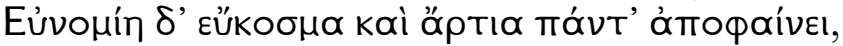

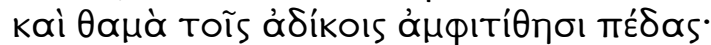

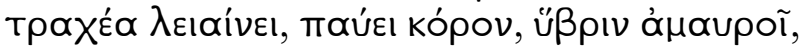

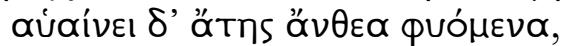

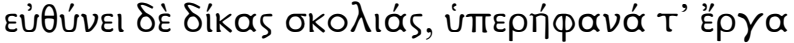

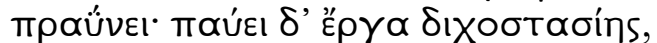

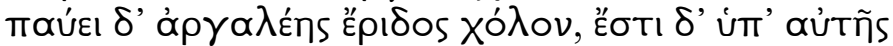

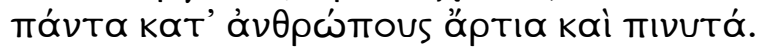

Our state will never be destroyed by the dispensation of Zeus or the intentions of the blessed gods: such a stout-hearted guardian, daughter of a mighty sire, Pallas Athene, holds her hands over it. But the citizens themselves are prepared to destroy a great city by their foolish actions, persuaded by wealth, and the mind of the people's leaders is unjust, who are certain to suffer much for their great insolence. They do not know how to restrain excess or conduct the joyful festivities of the banquet in peace ... and they grow rich, relying on unjust deeds ... sparing neither sacred nor public property, they steal by plunder all they can, nor do they respect the venerable foundations of Justice, who, silent, knows present and past, and in time assuredly comes to exact punishment. This is already coming upon the whole city as an inescapable wound, and swiftly it falls into vile slavery, which rouses strife within the tribe and sleeping war, destroyer of many's lovely youth. At the hands of its enemies the much-loved city is swiftly being torn apart in gatherings of those who wrong their friends. These evils roam at large among the people, and many of the poor are headed to foreign lands, sold and bound in shameful bonds ... And so the public ill comes home to everyone, and the courtyard doors refuse to hold it back any longer, but it leaps over the high wall, and finds him out for sure, even if he seeks refuge in the innermost recess of his room. This is what my heart bids me teach the Athenians: Lawlessness brings the city countless ills, but Lawfulness reveals all that is well ordered and fitting, and many a criminal it puts in shackles. It makes the rough smooth, curbs excess, weakens insolence, and shrivels up the budding flowers of delusion; it straightens out crooked judgements, restrains arrogant behaviour, ends discord and the anger of bitter strife. Under its power all men's affairs are fitting and rational.

Though the transmitted text lacks some verses, the lacunae are unlikely to be large, and it is the second longest piece of Solon's to have survived (fr. 13, the so-called 
Elegy to the Muses, being by far the longest). One of the most striking features of this poem is the way it applies the language of epic warfare to stasis, and so suggests that in Solon's world the dichotomies of war versus peace and enemy versus self do not work in contemporary Athens. ${ }^{14}$

The poem opens in lines 1-4 with the ultimate reassurance for an Athenian audience, the protection of their 'guardian' (Émírkomos) goddess. The epithet óßрıното́трп is unique to Athena and triggers the audience's awareness of her role in epic as Zeus' favourite child and the enforcer of his will, ${ }^{15}$ enhancing the status of

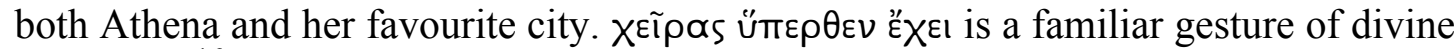
protection: ${ }^{16}$ Athena, then, will assuredly oppose the city's enemies. However, this turns out to be a red herring as the speaker turns our attention to internal enemies in lines 5-8, with the implication that even divine protection cannot help if you are fighting each other.

Lines 9-10 focus on typical benefits of peace ('the festivities of the banquet'), but make clear that the citizens are not capable of enjoying them. Solon is undermining the traditional dichotomy of war versus peace - one might think, for example, of the city at war and the city at peace depicted on Achilles' shield, where there are two modes: either you are at war, where there is bloodshed, but also divine support and opportunity to win glory; or you are at peace, where there is law and order, and the pleasures of stable life such as weddings and feasts (Il. 18.490-540). ${ }^{17}$ Solon departs from this by suggesting that in his world, though the Athenians are formally at peace, they have civil strife, which disrupts the dichotomy of enemy versus self and is harder to manage.

Lines 12-16 describe the greediness of the Athenian elite, but do so using the language of a sacked city (note especially á $ф \alpha \rho \pi \alpha \gamma \tilde{n} ı$, 'by plunder', line 13), ${ }^{18}$ where the enemy run amok and plunder shrines (here the shrine of Dike herself). Since this pillaging is internal, there is no 'us' versus 'them' as in a real war, and the selfishness of the factions is condemned.

As lines 17-22 make clear, the greediness of the leading citizens produces 'slavery' (18) - i.e. the oppression of the demos by the powerful elite - whose

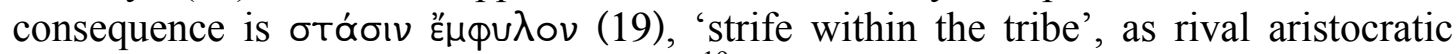
factions compete for money and power. ${ }^{19}$ In lines 21-2 the language of friends and

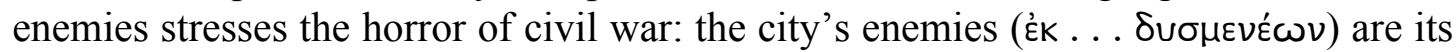
own citizens, and the damning word pínous (i.e. their fellow Athenians) is delayed for maximum effect. In the description of stasis itself in lines 19-20, the metaphor of

\footnotetext{
${ }^{14}$ Of course, the revenge meted out to the suitors in the Odyssey shows that the use of violence within a community is sometimes necessary and justified, but internecine strife is generally denigrated in epic (cf. e.g. Phoenix's account of Meleager's family in Il. 9.524-605 or the Nostoi's version of the unhappy homecomings endured by many returning heroes). Moreover, even Odysseus' violence sparks a civil war when the suitors' kinsmen seek to avenge their deaths (a danger foreseen by Odysseus himself: Od. 23.117-22), and it takes the intervention of Zeus and Athena to stop the bloodletting (Od. 24.52844).

${ }^{15}$ E.g. Il. 5.747, Od. 3.135; cf. Allan 2006: 20-1.

${ }^{16}$ E.g. Il. 24.374 , where Priam thinks a god may be helping him, but ironically does not understand how.

${ }^{17}$ Granted there is still violence in the city at peace, with a murder trial underway, but the emphasis is on the people's respect for the 'straightest judgement' that will avoid future vendetta violence (Il. 18.502-8).

${ }^{18}$ Fr. 34.1 similarly uses ápா $\alpha \gamma$ ń of internal plundering.

${ }^{19}$ otóoıs in the sense 'civil war' is first attested here.
} 
war awakened from its 'sleep', familiar from epic, ${ }^{20}$ is made more sinister by being applied to internal violence, while the destruction of Épaтì $\nu . . \dot{\eta} \lambda ı$ เínv evokes (typically Homeric) pity for the loss of 'lovely youth', but in a context of civil war which makes their killing peculiarly shocking.

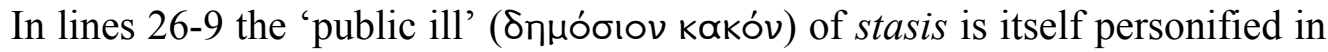
terms that evoke the animal similes of Homeric epic, as at Iliad 5.134-8:

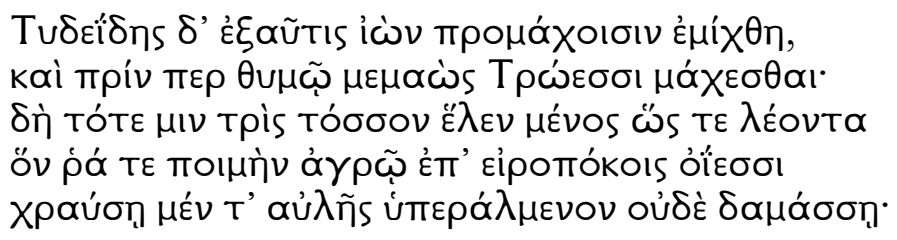

The son of Tydeus went back again and joined the front-fighters; and though his heart had been raging before to fight the Trojans, now three times that fury seized him, just as it does a lion that a shepherd, tending his thick-fleeced sheep in open country, has wounded but not killed when it leapt into the sheepfold.

Like the lion leaping over the fence and into the sheepfold ( $\propto u \dot{u} \lambda$ '), Solon's 'public ill'

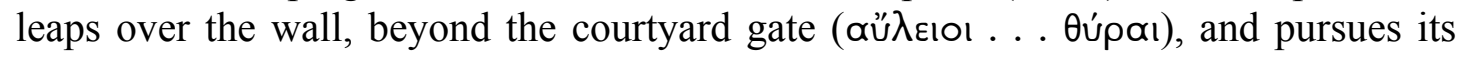

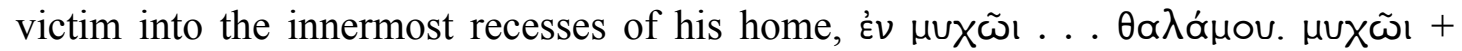
$\theta \alpha \lambda \alpha$ ámolósónou is also a Homeric phrase, used in domestic contexts to describe a place of intimacy and safety for husband and wife, as at Iliad 22.437-41 (cf. Il. 17.36, Od. 3.402, 4.304, 7.346):

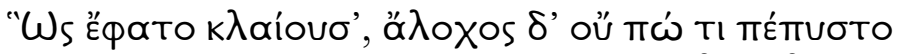

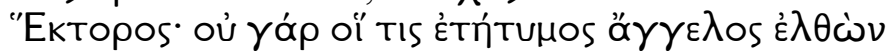

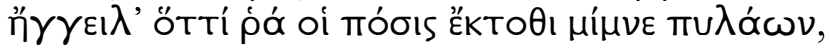

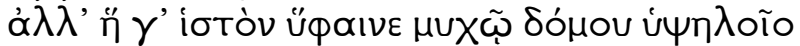

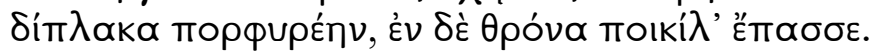

So she [Hecuba] spoke, weeping, but Hector's wife had not yet heard anything, for no trusty messenger had come to tell her that her husband had stayed outside the gates, but she was in the innermost part of their high house weaving a purple double cloak, and working a pattern of colourful flowers into it.

Just as domestic peace is undone in the Homeric passage by the impending death of Hector, so in Solon it is destroyed by the relentless violence of civil strife.

Overall, then, fr. 4 applies the language of epic to stasis, and suggests that in Solon's Athens the dichotomies of war versus peace, and enemy versus self, do not work. Thus the solution, at the end of the fragment, is not heroic martial endeavour, under the protection of the gods, but Eunomia - that is, a divine (and abstract) peacemaker or reconciler, replacing the function of a warrior. At line 32 Eunomia restores the kosmos ('order') which in line 10 was one of the hallmarks of peace

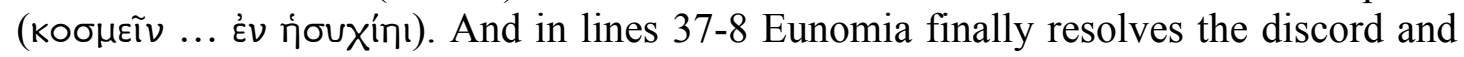
strife (dichostasie and eris) besetting the city.

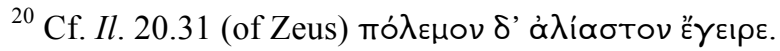


The manipulation of epic language and war imagery to support Solon's role as reconciler is even more evident in fr. $5:^{21}$

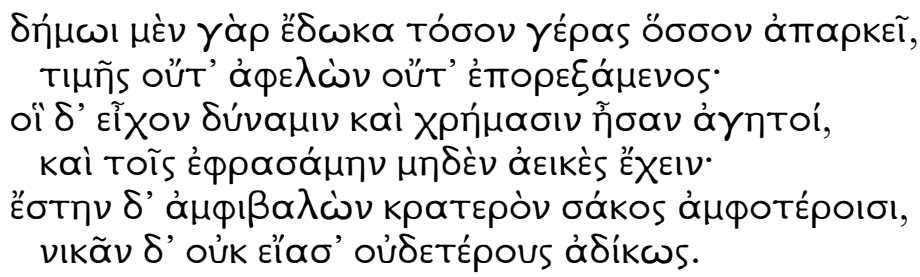

I gave the people as much privilege as is sufficient for them, neither detracting from their honour nor giving more; and as for those who had power and were admired for their wealth, I also made sure they suffered no indignity. I took my stand holding my mighty shield over both, and did not allow either side an unjust victory.

The piece is carefully structured not only to reflect the idea of balance ${ }^{22}-$ each group is given equal attention: $1-2$ on the $\delta \tilde{\eta} \mu o s, 3-4$ on the elite - but also to underline Solon's active authority and concern for all Athenians: he is the agent of the main verbs ( success in preventing 'an unjust victory' for either side. The poem is calculated to appeal to as wide a swathe of the Athenian audience as possible.

The language of time and geras in the opening couplet likens Solon to the ideal Homeric leader, who (unlike Agamemnon) knows how to apportion honour and privilege so as to create social harmony. But it is the concluding couplet that refashions martial imagery most strikingly, as Solon shields both sides in the conflict, stressing his fairness and concern for all Athenians. ${ }^{23}$ By uniting all citizens under one shield, and by raising the possibility of civil strife - especially in the 'unjust victory'

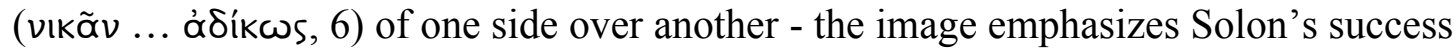

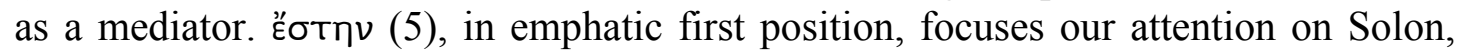
while the epic-sounding кратєрòv бákоs characterizes him as a resolute protector.

This defensive shield metaphor will also have reminded the sixth-century BC audience that they are all part of the same hoplite line. ${ }^{24}$ The idea of protecting your comrade with the shield evokes the behaviour of the good hoplite, but Solon is able to cover both sides with his shield, whereas a real hoplite could cover only one comrade. Solon, then, is not only a good Homeric leader but also a kind of super-hoplite, on whom everyone depends - thus closer to the epic hero in that regard than to the hoplites, where the point is that everyone is equally dependent on one another. So the

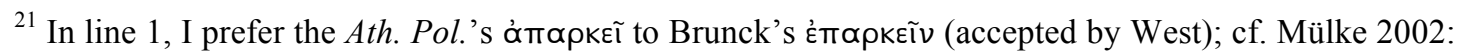
$186-7$.

${ }^{22}$ As Noussia-Fantuzzi 2010: 283 observes in her introduction to fr. 5, 'Plut. Sol. 14.4 recalls how the

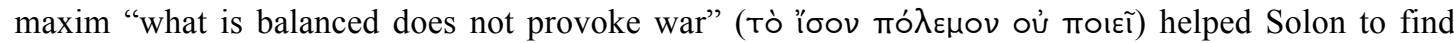
favor with the rich and the poor alike.'

${ }^{23}$ Solon's skilful adaptation of military language here is often underappreciated by commentators. Campbell 1982: 245 remarks "the metaphor "covering both sides with my stout shield" is not particularly happy', while Gerber 1970: 134 observes 'Solon clearly means that he protected both groups by his legislation, but the imagery used does not seem very appropriate.'

${ }^{24}$ van Wees 2004: 166-83 doubts the existence of the hoplite phalanx in the early archaic period. But even if he is right (and many do not share his scepticism), Solon's image of the protecting shield has a strong epic pedigree (take, for example, Teucer's tactic of taking shelter beneath Ajax's tower shield, Il. 8.266-72). The psychology and ideology of hoplite warfare in classical Athens, as discussed by Crowley 2012, continues this traditional insistence on mutual protection.
} 
imagery of war in fr. 5 communicates Solon's role as an outstanding and impartial protector, whose achievement has been to save the Athenians from unjust (i.e. internal) violence.

We find similarly bold use of the imagery of violence and protection at the end of fr. 36, which is one of the most fascinating surviving examples of the political use of iambus in the archaic period:

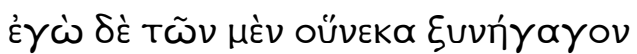

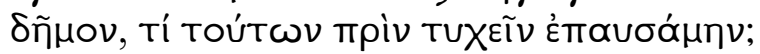

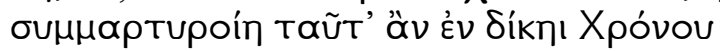

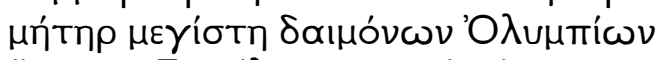

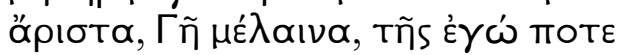

öpous åveĩ

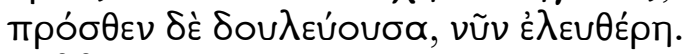

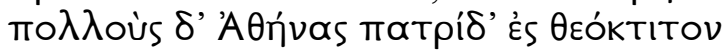

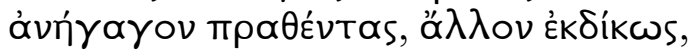

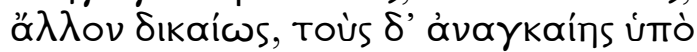

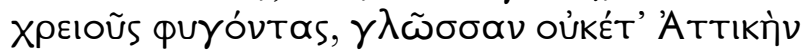

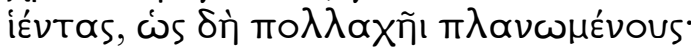

Toùs $\delta$ '

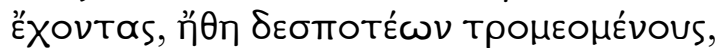

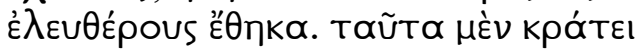

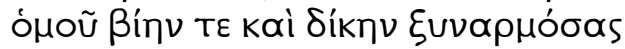

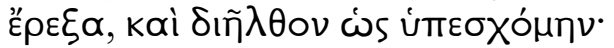

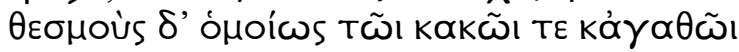

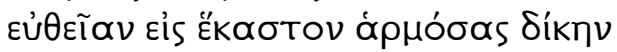

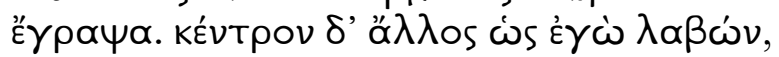

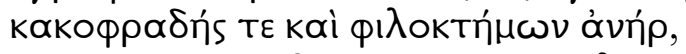

oủk åv kaT

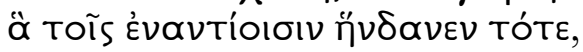

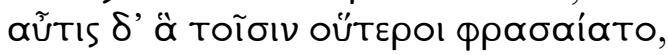

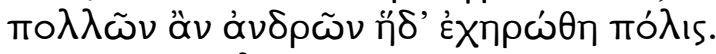

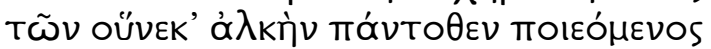

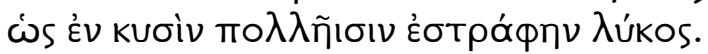

The aims for which I called the people together, which of these had I failed to achieve before I stopped? May I call as my best witness in the court of Time the mighty mother of the Olympian gods, black Earth, whose mortgage stones, fixed far and wide, I removed - slave before, now she is free. And to Athens, to their homeland founded by the gods, I brought back many who had been sold, some illegally, some legally, and others who had fled out of compelling need, no longer speaking the Attic tongue, so far and wide their wanderings. And others suffering shameful slavery right here, trembling at their masters' whims, I set free. These things I achieved by my power, combining force and justice, and I carried out all my promises. I wrote laws for the lowly and the noble man equally, creating straight justice for all. If another had wielded the goad as I did, an unscrupulous and greedy man, he would not have restrained the people. If I had been willing to do what the people's opponents wanted then, or in turn what the others had in store for them, this city would have been bereft of many men. So, defending myself on all sides, I turned about like a wolf amid a pack of dogs. 
As in the elegiac fr. 5, Solon here defends his policies as being in the best interests of all Athenians, and boasts of his resistance to the extreme demands made by both the $\delta \tilde{\eta} \mu O s$ and their wealthy opponents. By focusing on the liberation of the Athenian land (3-7) and its citzens (8-15), Solon foregrounds the damage to Athenian society caused by greed, debt and enslavement, and presents his unbiased reforms as having prevented civil war (22-5). ${ }^{25}$ But it is the concluding simile (26-7) that I want to draw attention to here, a simile that places Solon at the centre of events in a dramatically striking way.

Solon's wolf simile is highly ironic and stresses the ingratitude of the Athenians who attacked him because of his reforms. Although Solon worked for the whole community, their reaction has forced him into the role of the wolf, while the two sides, the $\delta \tilde{n} \mu o s$ and its opponents, have united (like a dog pack) to attack him, despite their incompatible interests. As with the shield simile of fr. 5, the animal simile here evokes Homeric epic, and adapts epic imagery to suit the new and disturbing context of civil war. ${ }^{26}$ In contrast to the shield simile, however, where Solon stands in the middle protecting both sides, here he is forced into the middle because he is under attack from all sides. Once again there is play on 'who is the enemy?' - in fr. 5 the implication was 'no one, we're all on the same side'; but here Solon is being treated as if he were the enemy, despite his beneficent behaviour. As in the other poems we have looked at, the citizens are incapable of distinguishing self from enemy.

Solon's simile in fr. 36 only becomes clear with the final word ( $\lambda$ úkos), enhancing its impact. Since the wolf can have positive as well as negative associations in Greek thought, Solon's image works in different ways, but all to his advantage. As an animal known for its independence - one might compare the fable ( 346 Perry) of the 'free' wolf, who rejects the easy but 'slavish' life of the $\operatorname{dog}^{27}-$ it highlights Solon's courage in sticking to his principles and refusing to serve either side. On the other hand, the wolf's reputation as a selfish predator (even turning on its

\footnotetext{
war.' animals of choice.'

${ }^{27}$ Babrius, Aesopic Fables in Iambic Verse $100=346$ Perry, trans. B. E. Perry:

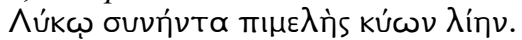

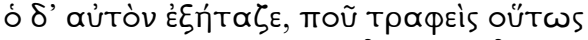

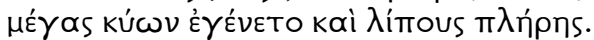

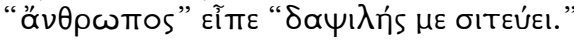

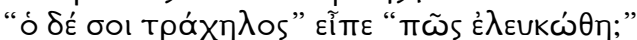

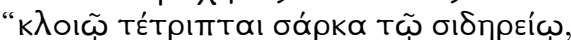

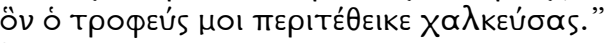

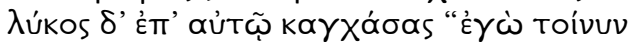

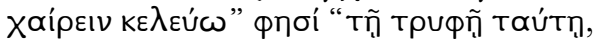

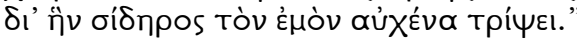

${ }^{25}$ Cf. Noussia-Fantuzzi 2010: 481-2 on 36.23 'Évavtíos is attested as a noun for the first time here; it was mainly predicative in Homer and Hesiod. When used in a hostile sense it focuses on the physicality of staying or moving "in front"/"against", and thus better than other more abstract designations of the enemies (like $\varepsilon^{X} \theta \rho o$, по

${ }^{26}$ As Irwin 2005: 245-6 observes, 'on closer analysis, the simile's Homeric sheen creates a paradox: from a Homeric perspective Solon's besieged wolf is an impossibility. As several have noted, wolves never appear in Homeric similes in the singular - they are always collective - and therefore wolves never feature in the stock simile of the beleaguered single wild animal, in which lions and boars are the

A dog who was very plump met with a wolf who began to question him: Where was he fed that he had become such a big dog and so well lined with fat? 'A rich master feeds me,' said the dog. 'But your neck,' asked the wolf, 'how came the bare spot on it?' 'The flesh has been rubbed by the iron collar which my keeper forged and put upon me.' The wolf laughed at him mockingly and said: 'Away with that kind of luxury! It's not for me at the cost of having my neck frayed with an iron collar.' 
fellow wolves to get its prey ${ }^{28}$ ) emphasizes Solon's unfair treatment as an outsider, as he, the saviour of his community, is attacked by the group (the dog pack) and cast in the role of the anti-social animal.

My final example of the transformation of martial imagery comes from fr. 37, where Solon rebukes both sides for complaining that they did not get what they wanted:

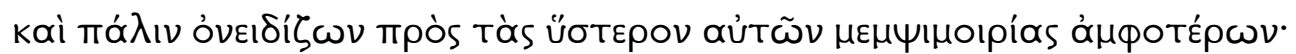

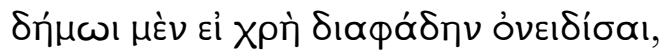

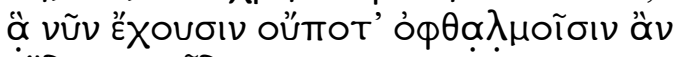
EÜठOVTES EİठOV ...

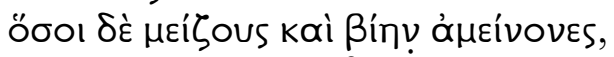

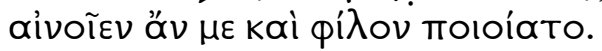

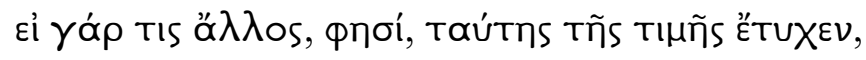

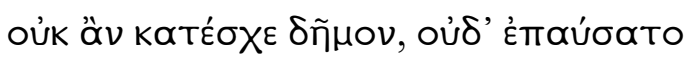

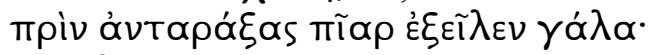

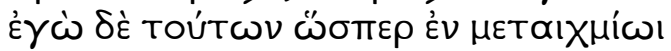
öpos katéotฤv.

Again, reproaching both parties for the complaints they made afterwards:

If I am to reproach the people openly, I say that what they now have they would never even have dreamt of ... And those who are bigger and stronger should praise me and call me friend.

For if some other man, he says, had obtained this position,

He would not have restrained the people, nor have stopped until he had churned the milk and lost the cream. ${ }^{29}$ But I took my stand between them like a boundary stone in no-man's land.

In the concluding image, a striking mixed metaphor, Solon compares himself to a

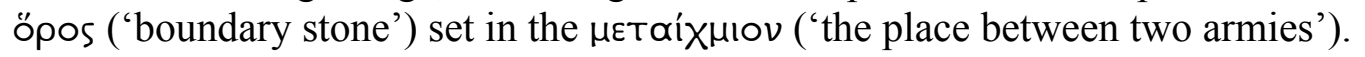

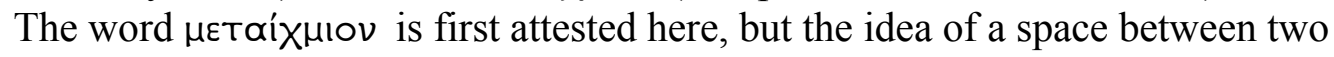
armies is a traditional feature of epic, and evokes those scenes where a warrior comes forward to challenge an opponent to face-to-face combat (e.g. Paris' ill-advised

\footnotetext{
${ }^{28}$ Cf. e.g. Iliad 4.470-2 (Agenor (Trojan) has killed Elephenor with a spear-thrust to the ribs):

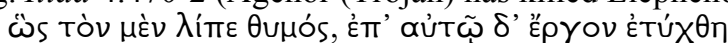

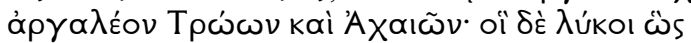

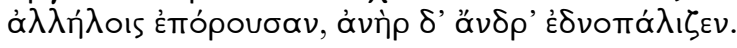

So the life left him, and there was painful work for Trojans and Achaeans over his body. Like wolves they leapt upon each other, and man hurled man in the fray.

${ }^{29}$ Though Solon chastizes both groups for their ingratitude, it should be noted that he diplomatically flatters the aristocracy by calling them the 'cream' of Athenian society (37.8). Strictly speaking,

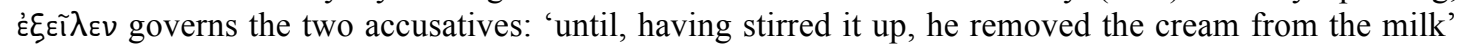
or 'deprived the milk of its cream'; see West 1974: 182, Stinton 1976: 160. Noussia-Fantuzzi 2010: 494 interprets the 'lactic realities' of the poem otherwise, and regards mĩ $\rho$ as "not the "cream" of society, but the wealth wrongly taken from the people, who, to push this metaphor, are now like lowfat milk', but I find this reading unconvincing. 
challenge to the Achaeans at the start of the real fighting in the Iliad, a challenge met by Menelaus, Il. 3.21-9). Here, by contrast, Solon is coming out into the middle to reconcile the two sides, who are depicted as warring enemies. Significantly, when Paris shrinks back in fear, Hector secures his commitment to fight and then strides between the two sides and prevents further fighting so that the duel can commence (Il. 3.30-94). So while Solon's role as reconciler contrasts with Paris' entry into the middle as a challenger, it can be seen as a development of Hector's attempt to end the fighting once and for all.

The area between two armies is, of course, meant to be crossed since that is where, in normal circumstances, victory is sealed and glory won, but this is a civil

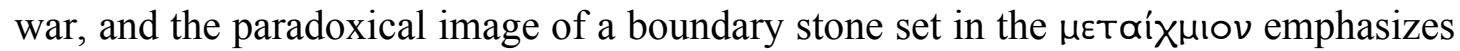
the unacceptability of internal conflict. At line 6 of fr. 36 (see above) Solon boasted of removing the öpous (in the sense of 'mortgage stones') from the land of Attica. ${ }^{30}$ Here in fr. 37 , however, Solon himself is the öpos, the boundary stone in a positive sense, between the warring factions (the $\delta \tilde{n} \mu o s$ and the ruling elite). The image of the boundary stone suggests that there is a genuine distinction between the two parties, but also emphasizes that their conflict is best resolved not by civil war but by negotiated agreement, i.e. a lawful boundary-marker, a symbol of peace embodied by Solon himself. A Homeric simile applied to the battling Achaeans and Trojans makes a similar point (Il. 12.421-4):

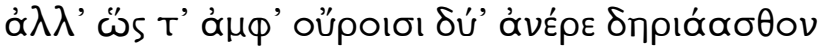

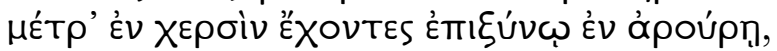

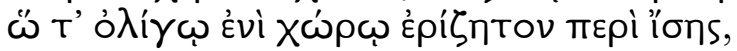

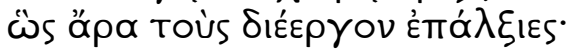

But as two men quarrel over the boundary stones in a common field, each holding measuring-rods in their hands, and wrangle over their fair share of a small piece of ground, so the battlements kept the two sides apart.

As in Solon's image, the farmers' measuring-rods suggest the possibility of a peaceful settlement.

Finally, it is worth noting that in their role as boundary stones öpo are also used to mark the limits of sacred land (see LSJ s.v. II c), and in that sense too we naturally find the word in the plural, since more than one stone is needed to define a temple's territory. Solon's singular öpos is therefore highly unusual, not only underlining his position of courageous isolation, but also perhaps exploiting the sacred associations of the öpos to bolster his political authority.

In conclusion, then, we can see Solon using two strategies in particular to communicate the importance of his role as peacemaker: the first is the way he applies military language and metaphors to political situations and relationships in order to highlight the evils of stasis $;{ }^{31}$ the second is the way he recasts traditional imagery of

\footnotetext{
${ }^{30}$ For the term öpos ('mortgage stone') in Athenian law, see Harrison 1968-71: 1.257. Some have doubted the traditional interpretation of öpor as markers of mortgaged land and a sign of indebted 'sixth-parters' or hektemoroi, but see de Ste. Croix 2004: 107-28. In any case, it is clear that the öpol of fr. 36 symbolize (in Solon's view) a damaging state of servitude between small farmers and their overlords.

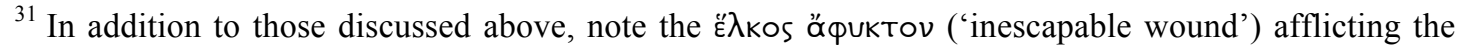
city (fr. 4.17), the pú $\mu \alpha \tau \alpha$ ('defences') of the demagogues (fr. 11.3), and Solon's rejection of tyranny

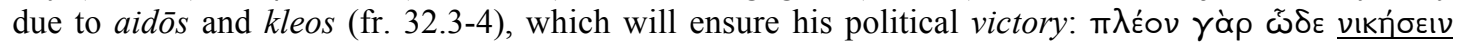

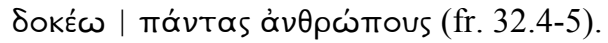


warfare and violence in order to highlight his efforts, and his success, as a 'reconciler' ( $\left.\delta 1 \alpha \lambda \lambda_{\alpha \kappa} \alpha_{n}\right)$ of the warring parties. As Nestor says in the Iliad (9.63-4):

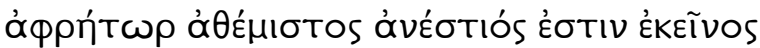

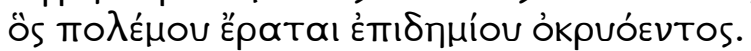

'Clanless, lawless, hearthless is the man who loves the horror of war within his own people.'

Solon's poetry builds on this basic truth, and recasts traditional epic imagery so that his audience, in the shadow of civil war, will grasp the benefits of peace and reconciliation. $^{32}$

\footnotetext{
${ }^{32}$ A shorter version of this contribution appeared as Allan, W. 2017. "Solon the peacemaker", in E. P. Moloney and M. S. Williams (eds.), Peace and Reconciliation in the Classical World. Abingdon: Routledge. 15-26.
} 


\section{Works cited}

Allan, W. 2006. "Divine Justice and Cosmic Order in Early Greek Epic," JHS 126: 135.

Blok, J. H. and A. P. M. H. Lardinois (eds.). 2006. Solon of Athens: New Historical and Philological Approaches. Leiden: Brill.

Cairns, D. L. 1993. Aidoss: The Psychology and Ethics of Honour and Shame in Ancient Greek Literature. Oxford: Oxford University Press.

Campbell, D. A. 1982. Greek Lyric: A Selection of Early Greek Lyric, Elegiac and Iambic Poetry, $2^{\text {nd }}$ edn. Bristol: Bristol Classical Press.

Crowley, J. 2012. The Psychology of the Athenian Hoplite: The Culture of Combat in Classical Athens. Cambridge: Cambridge University Press.

de Ste. Croix, G. E. M. 2004. Athenian Democratic Origins. Oxford: Oxford University Press.

Forsdyke, S. 2006. "Land, Labor and Economy in Solonian Athens: Breaking the Impasse between Archaeology and History", in Blok and Lardinois 2006: 334350.

Gerber, D. E. 1970. Euterpe: An Anthology of Early Greek Lyric, Elegiac and Iambic Poetry. Amsterdam: A. M. Hakkert.

Harris, E. M. 2002. “Did Solon Abolish Debt-bondage?”, CQ 52: 415-430.

Harrison, A. R. W. 1968-71. The Law of Athens. 2 vols. Oxford: Oxford University Press.

Irwin, E. 2005. Solon and Early Greek Poetry: The Politics of Exhortation. Cambridge: Cambridge University Press.

Kearns, E. 1989. The Heroes of Attica. London: Institute of Classical Studies.

Lewis, J. 2006. Solon the Thinker: Political Thought in Archaic Athens. London: Duckworth.

Manville, P. B. 1990. The Origins of Citizenship in Ancient Athens. Princeton: Princeton University Press.

Mülke, C. 2002. Solons politische Elegien und Iamben (Fr. 1-13; 32-37 West): Einleitung, Text, Übersetzung, Kommentar. Munich: K. G. Saur.

Noussia-Fantuzzi, M. 2010. Solon the Athenian: the Poetic Fragments. Leiden: Brill.

Rhodes, P. J. 2006. "The Reforms and Laws of Solon: An Optimistic View," in Blok and Lardinois 2006: 248-260.

Stanley, P. V. 1999. The Economic Reforms of Solon. St Katharinen: Scripta Mercaturae Verlag.

Stinton, T. C. W. 1976. "Solon, Fragment 25," JHS 96: 159-62.

van Wees, H. 2004. Greek Warfare: Myths and Realities. London: Duckworth.

West, M. L. 1974. Studies in Greek Elegy and Iambus. Berlin: Walter de Gruyter.

West, M. L. ed. 1992. Iambi et Elegi Graeci ante Alexandrum cantati, vol. 2, $2^{\text {nd }}$ edn. Oxford: Oxford University Press. 